\title{
Influence of Air-tightness on Heat Energy Performance in Post and Beam Building with Exposed Wood Frame*1
}

\author{
Hyun-bae Kim*2, Sejong Kim², Jung-kwon $\mathrm{Oh}^{* 3}$, \\ Joo-saeng Park ${ }^{* 4}$, and Jun-jae Lee*3†
}

\begin{abstract}
Han-green building is one of the modernized Korean traditional buildings developed by Korea Forest Research Institute. This building was developed to increase the competitiveness of Korean traditional building using state-of-art technologies; hence Han-green building has the inherent characteristics of traditional building such as exposed wood frame in wall. Because of discontinuity in wall by the exposed wood frame, there is a concern on heat-air leaking in terms of energy performance. In this study, air-tightness of Han-green building was evaluated to investigate the influence of gaps between frames and in-fill walls. Blower door test was carried out to evaluate the air-tightness, and air-change rate (ACH50) was evaluated by averaging four set of pressurization and depressurization test. The air-change rate of Han-green house was $5.91 \mathrm{~h}^{-1}$. To improve energy performance of Han-green house, thermal infrared images of Han-green house were taken in winter with heating to find out where the heat loss occurred. It was found that the building lost more heat through gaps between frames and in-fill walls rather than through other parts of this building. After covering all the gaps by taping, the blower door test was performed again, and the air-change rate was improved to $5.25 \mathrm{~h}^{-1}$. From this analysis, it was concluded that the heated air can leak through the gaps between frames and walls. Therefore, when one designs the post and beam building with exposed frame, the detail design between frame and wall needs to be carefully dealt. However, Han-green building showed relatively high air-tightness comparing with other country research results.
\end{abstract}

Keywords : Air-tightness, post and beam, energy consumption, low energy timber frame house

\section{INTRODUCTION}

Nowadays, the Korean government has recognized the importance of Korean identity and branding a national architectural style with value. Through the technical development for modern- ization of Korean traditional building, Korean government set a goal to improve the quality and value of Korean traditional buildings. As a result of the efforts, Korea Forest Research Institute (KFRI) developed a modernized Han-ok, named as "Han-green".

*1 Received on September 5, 2012; accepted on September 18, 2012

*2 Department of Forest Sciences, Seoul National University, Korea

*3 Department of Forest Sciences, Seoul National University, Research Institute for Agriculture and Life Science

*4 Div. of Wood Engineering, Dept. of Forest Products, Korea Forest Research Institute, Seoul

† Corresponding author : Jun-jae Lee (e-mail: junjae@snu.ac.kr) 


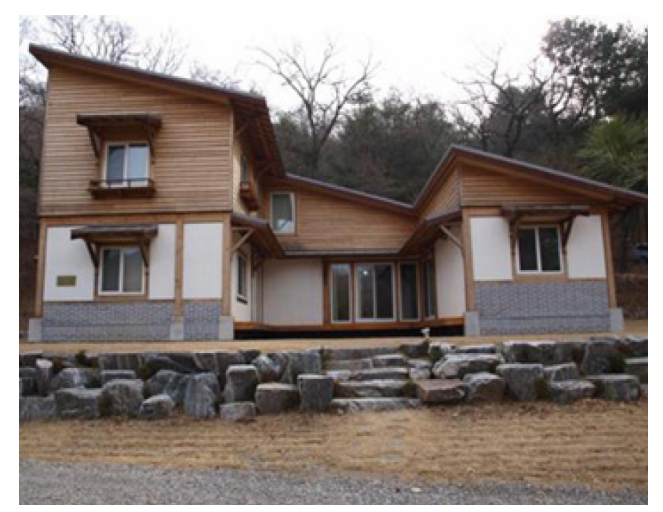

Fig. 1. Picture of "Han-green" house.

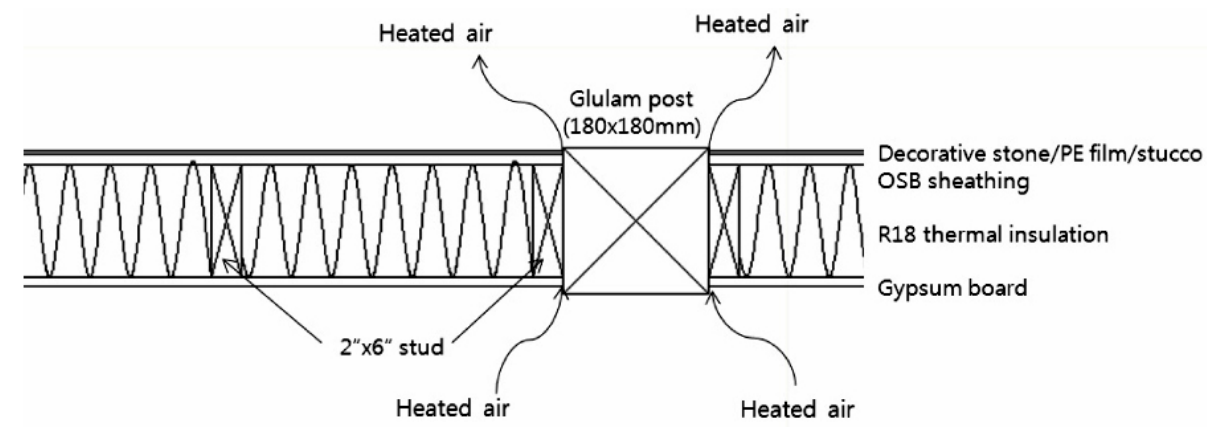

Fig. 2. Expected air-leaking.

There is world-wide interest in energy saving of residential building. According to statistics 2008 of KEEI (Korea Energy Economics Institute), heating energy accounts for higher than $10 \%$ of national energy consumption in residential building. The modernized Han-ok, Han-green, consist of glulam post and beam as load-bearing members and in-fill wall of light frame. In this type of building, the in-fill wall is not structural element and it just divides space into rooms. The glulam posts and beams are exposed in both sides as Fig. 1 shows. There might be small gaps between frames and in-fill walls, and the gap might be bigger with time because of difference in shrinkage rate. Because the heated air can be leak through this gap, air-tightness need to be checked whether the glulam frame and in-fill wall efficiently prevent heated air fromleaking or not. Moreover, to estimate the heating energy demand, air-tightness is one of basic input variables with thermal insulation property. Therefore, the air-tightness of Han-green house needs to be evaluated for further studies on energy efficiency.

Many researches on air-tightness have been carried out. Blower door test method is widely used to evaluate air-tightness. Extensive researches have been carried out by the blower door test to measure the air-tightness of residential building in a specific region (Stein and Meier, 2000; Kalamees, 2006; Sfakianaki et al., 2008; Montoya et al., 2009; Sinnott and Dyer, 
2011; and Alfano et al, 2011). Also, the blower door test method was used to improve energy efficiency of building (Relander et al., 2010; Langmans et al., 2010; Nabinger and Persily, 2011).

In Korea, researches on air-tightness have been carried out since the 1980s. Park and Yoon (2003) measured air-tightness by gas-tracer method and blower door test. The blow door test method has been applied to several different types of residential building; detached houses (Yoon et al, 2008), studio (Kim et al, 2008) and high-rise condo (Koo et al, 2008). Most of research on air-tightness in Korea has been performed on only reinforced-concrete and steel frame buildings.

This study is a part of effort to improve the energy efficiency of Han-green house. For the first step, this study was aimed at the evaluation of the air-tightness of Han-green house, because air-leakage had been expected to be main cause to decrease energy efficiency of Han-green house. Also, the influence of air-leakage on energy efficiency was investigated by preventing heated air from leaking between frame and in-fill wall by taping.

\section{MATERIALS and METHODS}

\subsection{Materials}

Two year old Han-green house in Korea National Arboretum, Gwang-neung, Gyeonggi-do was chosen as a specimen (Fig. 1). The area of the first floor and second floor is $126.1 \mathrm{~m}^{2}$ and $63.3 \mathrm{~m}^{2}$ respectively and air volume of this building was $584.7 \mathrm{~m}^{2}$. This building had 180 $\mathrm{mm}$ by $180 \mathrm{~mm}$ glulam post and in-fill walls which were made of $38 \mathrm{~mm}$ by $140 \mathrm{~mm}$ stud, gypsum board and OSB (Fig. 2). The glulam post \& beam frame was exposed as Fig. 1 shows and air-leaking was expected to be oc-

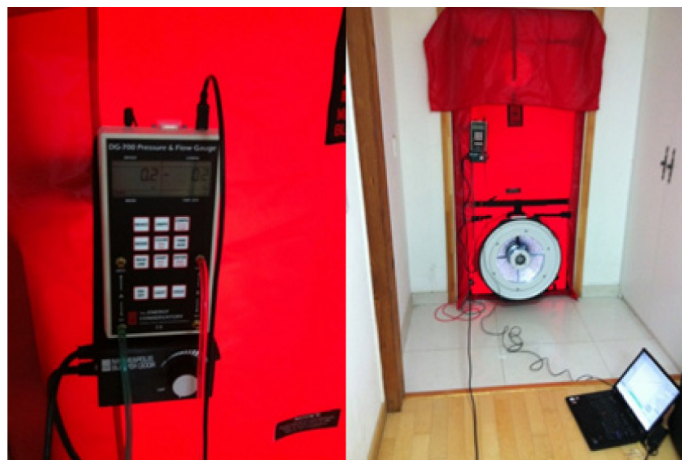

Fig. 3. Picture of equipment for blower door test (Minneapolis Blower Door Model 3, The Energy Conservatory co. Itd.).

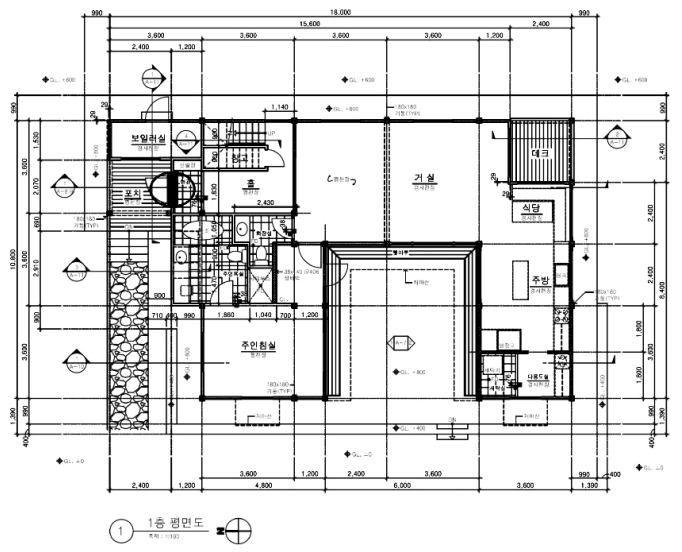

Fig. 4. Floor plan of tested building and location of blower door (blower door was installed at the shaded area).

curred as Fig. 2 shows.

\subsection{Methods}

\subsubsection{Air-tightness Evaluation by Blower Door Test}

Air-tightness was evaluated by the blower door test following ASTM E 779-03. In this study, Minneapolis Blower Door Model 3 (The 


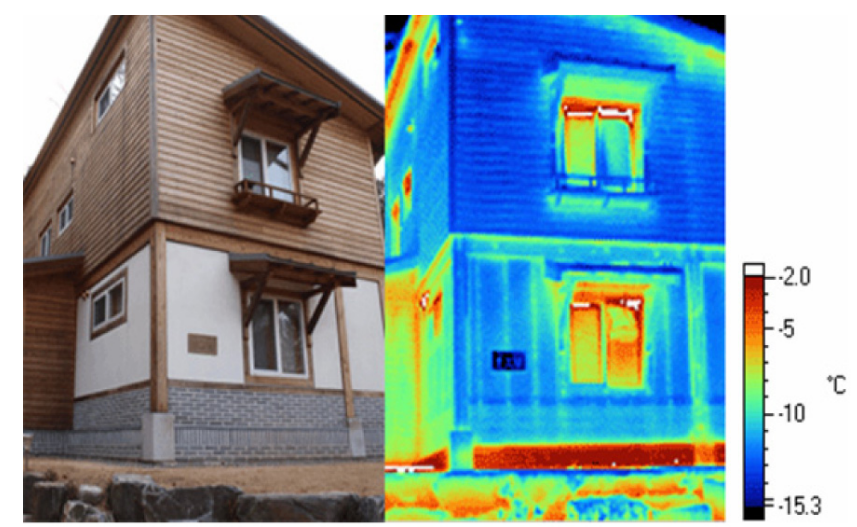

Fig. 5. Thermal image analysis to find heat loss.

Energy Conservatory co. ltd.) was used (Fig. 3). The blower door was installed at the gate of the building as Fig. 4 shows. During the test all windows and other doors in building envelope were closed and inside doors were open. For pressurization, the fan in the blower door blew air from outdoor to indoor and the fan measured the air volume (CFM50) blown to make $50 \mathrm{~Pa}$ of pressure difference between outdoor and indoor. For depressurization, the blow direction was switchedand the air volume was measured in the same manner. Four sets of pressurization and depressurization were carried out. The mean value of the four test sets was used for analysis.

For air-tightness evaluation, air-change rate at pressure difference of $50 \mathrm{~Pa}(\mathrm{ACH} 50)$ is widely used. The calculation of $\mathrm{ACH} 50$ requires the amount of air flow (CFM50) to keep a specific pressure difference between indoor and outdoor as an input. The CFM50 was measured by blower door test. Air-change rate at $50 \mathrm{~Pa}$ pressure (ACH50) of Han-green house was calculated by Eq. 1.

$$
A C H 50=\frac{C F M 50 \times 60}{V}
$$

Where, ACH50 is air-change rate $\left(\mathrm{h}^{-1}\right)$ at pressure difference of $50 \mathrm{~Pa}, \mathrm{~V}$ is volume of building $\left(\mathrm{m}^{3}\right)$ and CFM50 is total airflow through the building envelope $\left(\mathrm{ft}^{3} / \mathrm{min}\right)$ when there is $50 \mathrm{~Pa}$ pressure difference between indoor and outdoor. In Eq. 1, number ' 60 ' is just for changing unit from per minute to per hour.

\subsubsection{Estimated of Energy Consumption}

The energy performance of Han-green house was evaluated by commercial software, CE3 simulation (P\&D soft co. ltd.). The CE3 software was developed with consideration of domestic situation, based on international standards ISO 13790 which follows the European EPBD (Energy Performance of Building Directives) and German evaluation standards DIN 18599.

Floor space, volume and composition of the wall of the first and second floor were used as input variables of CE3 simulation. The ACH50 evaluated at 2.2.1 was also used in this simulation.

\subsubsection{Thermal Images to Look for Heat-air Leaking}

Thermal images of Han-green house were 
Influence of Air-tightness on Heat Energy Performance in Post and Beam Building with Exposed Wood Frame
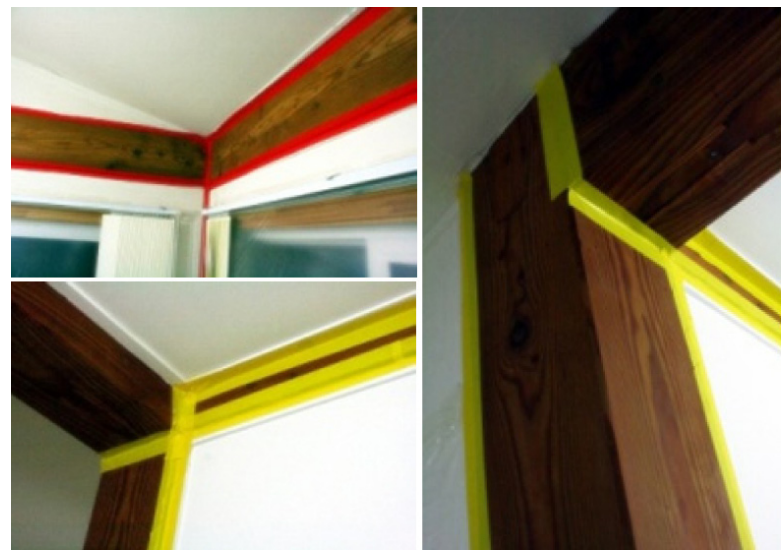

Fig. 6. Taping the gaps between frame and wall.

Table 1. Comparison of air change according to the presence of taping (unit : $\mathrm{ACH} 50, \mathrm{~h}^{-1}$ )

\begin{tabular}{cccc}
\hline & Pressurization & Depressurization & Mean \\
\hline \hline Without taping ${ }^{1)}$ & 6.07 & 5.74 & 5.91 \\
With taping & 5.36 & 5.13 & 5.25 \\
Difference & $-0.71(-11.7 \%)$ & $-0.61(-10.6 \%)$ & $-0.66(-11.2 \%)$ \\
\hline
\end{tabular}

${ }^{1)}$ Taping was applied to prevent heated air from leaking through gap between frame and wall

taken in winter with heating by portable Infrared camera (IR Flexcam, Infrared solutions co. Itd.) to find where the heat loss occurred (Fig. 5).

\subsubsection{Influence of Gaps Between Frames and In-fill Walls on Air-tightness}

To investigate the influence of gaps between frames and walls on air-tightness and energy efficiency, all possible air-leaking areas between frames and walls were blocked by taping as Fig. 6 shows. The blower door test and CE3 simulation were conducted in the same way and all input variables except air-change rate (ACH50) was the same as the simulation without taping. For the air-change rate (ACH50), the mean value of four tests with taping was used. Lastly, heating energy demands and annual energy demands were compared with the simulation without taping.

\section{RESULTS and DISCUSSIONS}

\subsection{Air-tightness of Han-green House}

Table 1 shows air-change rate (ACH50) evaluated by blower door test. Four pressurization/depressurization method were carried out and the mean value of the four test results. It showed that mean air-change rate (ACH50) of Han-green house was $5.91 \mathrm{~h}^{-1}$. 
Hyun-bae Kim, Sejong Kim, Jung-kwon Oh, Joo-saeng Park, and Jun-jae Lee

Table 2. Air-tightness of the domestic and overseas single-family homes

\begin{tabular}{cccccc}
\hline \multirow{2}{*}{ Country } & \multirow{2}{*}{ Year } & Number of building & \multicolumn{3}{c}{ Air-change rate $\left(\mathrm{ACH} 0, \mathrm{~h}^{-1}\right)$} \\
\cline { 4 - 6 } & & 12,902 & Mean & Min & Max \\
\hline \hline USA & & 29.7 & 0.5 & 84.0 \\
Canada & $1985-1995$ & 471 & 3.1 & 0.4 & 11.0 \\
UK & & 51 & 13.1 & 2.0 & 30.0 \\
Belgium & $1995-1998$ & 44 & 7.8 & 1.8 & 25.0 \\
Sweden & & 171 & 1.0 & & \\
Finland & $1981-1998$ & 100 & 5.9 & 1.6 & 1.8 \\
Finland & $2002-2004$ & 61 & 3.9 & 0.5 & 8.9 \\
Norway & 1980 & 22 & 4.7 & 2.0 & 8.0 \\
Korea & 2008 & 22.0 & 16.4 & 4.7 & 31.6 \\
(Chung-cheong) & & & & \\
\hline
\end{tabular}

Source : Yoon et al, 2008

Table 2 shows that Han-green house has lower air-change rate (ACH50) than USA, UK, Belgium and is similar to Finland in 80 90's. Also, it shows much better performance than Chung-cheong, Korea, which might be the in vestigation of reinforced concrete (RC) building because most residential building in Korea is RC. This lower air-change rate (ACH50) means that Han-green house has relatively better airtightness performance than other countries except cold region countries such as Finland, Norway and Canada. It is noticeable that the air-tightness of Han-green showed much better performance than the results of Chung-cheong region in Korea.

\subsection{Thermal Images to Look for Air Leaking}

Thermal images of Han-green house were taken in winter with heating, to find where the heat loss occurred. The bright part of the thermal imaging means heat loss. As Fig. 5 shows, the heat loss of Han-green house mostly occurred between the post / beam frames and in-fill walls than other post \& beam of this building.

Additionally, the Han-green building has a concrete foundation, and floor heatingsystem was installed on the foundation with thin insulation film. From analysis of thermal images, heat conduction through ground is one of the main causes of heat loss. However, this study focused on improvement of energy efficiency of timber structure and the problem in heat conduction of concrete foundation need to be dealt in future.

\subsection{Influence of Gaps between Frames and Walls on Energy Consumption}

Based on thermal image analysis, the gaps between frames and in-fill walls might be a passage of heated-air leak. Therefore, all possible air-leaking area between frame and in-fill wall were blocked by PVC tape (K\&T co. ltd.). By comparison of air change rate from the result without taping, it was investigated how much heated air can leak through the gap.

Mean air-change rate (ACH50) without tap 
Influence of Air-tightness on Heat Energy Performance in Post and Beam Building with Exposed Wood Frame

Table 3. Heating energy demand per a year for Han-green

\begin{tabular}{cccc}
\hline & Without taping & With taping & Difference \\
\hline \hline $\begin{array}{c}\text { Heating energy demand per unit area } \\
\left(\mathrm{kWh} / \mathrm{m}^{2} \cdot \mathrm{a}\right)\end{array}$ & 134.5 & 130.7 & $-3.8(-2.8 \%)$ \\
$\begin{array}{c}\text { Fossil fuel demand per unit area } \\
\left(\ell / \mathrm{m}^{2} \text { year }\right)\end{array}$ & 13.5 & 13.1 & $0.38(-2.8 \%)$ \\
$\quad \begin{array}{l}\text { Fossil fuel demand of } \\
\text { whole Han-green house } \\
\quad(\ell / \text { year })\end{array}$ & 2547.4 & 2475.5 & $71.9(-2.8 \%)$ \\
\hline
\end{tabular}

ing was $5.91 \mathrm{~h}^{-1}$ and the taping decrease the air-change rate to $5.25 \mathrm{~h}^{-1}$. Blocking the possible air-leaking area improved the air-tightness in $11.2 \%$. This means that air can leak between glulam frame and in-fill wall and it need to be carefully considered when this type of building is designed.

\subsection{Heating Energy Demand}

Table 3 was the result of annual heating energy demand from CE3 simulations. Annual heating energy demand was $134.5 \mathrm{KWh} / \mathrm{m}^{2} \cdot \mathrm{a}$ without taping, but it decreased to $130.7 \mathrm{KWh} / \mathrm{m}^{2}$ - a by taping. Accordingly, $3.8 \mathrm{KWh} / \mathrm{m}^{2} \cdot \mathrm{a}(2.8 \%)$ can be saved by taping the gaps. In other words, $0.38 \mathrm{l} / \mathrm{m}^{2}$ of fossil fuel per unit floor area can be saved for a year by blocking airleakage between frame and in-fill wall. However, because air-tightness makes smaller effects on energy consumption in building than other factors such as wall composition, the block of the gap by taping reduced only $2.8 \%$ of heating energy demand.

As it mentioned in previous clause, Hangreen house has relatively high air-tightness performance comparing other countries, even though the heated air can leak between frame and in-fill wall. However, for improvement of energy efficiency and development of low-energy building, the gaps need to be carefully dealt.

\section{CONCLUSION}

Air-tightness of the post-beam timber frame house, Han-green house, was measured by blower door test. It was concluded that Hangreen house has relatively high air-tightness performance comparing with other countries, even though heated air can leak through the gaps between frames and in-fill walls.

The gaps between frames and in-fill walls were expected to provide a great passage of heat loss. Based on the comparison the air-tightness from the test result preventing heated air leakage through the gaps, the air leakage through the gaps decreases the air-tight performance by $12 \%$. Therefore, when improving energy efficiency of the post and beam building which has exposed wood frame for the aesthetic features of the building, the detail design between frame and in-fill wall needs to be dealt with care.

\section{REFERENCES}

1. Stein, J. R. and A. Meier. 2000. Accuracy of energy rating systems. ENERGY 25: 339 354 .

2. Kalamees, T. 2007. Air tightness and air leakages of new lightweight single-family detached house in Estonia. Building and environment 42: 2369 2377.

3. Sfakianaki, A., K. Pavlou, M. Santamouris, I. 
Hyun-bae Kim, Sejong Kim, Jung-kwon Oh, Joo-saeng Park, and Jun-jae Lee

Livada, M.-N. Assimakopoulos, P. Mantas, and A. Christakopoulos. 2008. Air tightness measurements of residential houses in Athens, Greece, Building and Envirionment 43: 398 405.

4. Montoya, M. I., E. Pastor, F. R. Carrie, G. Guyot, and E. Planas. 2010. Air leakage in Catalan dwellings: Developing an airtightness model and leakage airflow predictions, Building and Environment 45: $1458 \sim 1469$.

5. Sinnott, D and M. Dyer. 2012. Air-tightess field for dwelling in Ireland. Building and environment 51: $269 \sim 275$.

6. Alfano, F. R., M. Dell'sIsola, G. Ficco, and F. Tassini. 2012. Experimental analysis of air tightness in Mediterranean buildings using the fan pressurization method. Building and environment 53: $16 \sim 25$.

7. Relander, T.-O., T. Kvande, and J. V. Thue. 2010. The influence of lightweight aggregate concrete element chimneys on the airtightness of wood-frame houses, Energy and Buildings 42: $684 \sim 694$.

8. Relander, T.-O., G. Bauwens, S. Roels, J. V. Thue, and S. Uvslokk. 2011. The influence of structural floors on the airtightness of woodframe houses, Energy and Buildings 43: 639 652.

9. Relander, T.-O., B. Heiskel, and J. S. Tyssedal. 2011. The influence of the joint between the basement wall and the wood-frame wall on the airtightness of wood-frame houses, Energy and Buildings 43: $1304 \sim 1314$.

10. Langmans, J., R. Klein, M. D. Paepe, and S. Roels. 2010. Potential of wind barriers to assure airtightness of wood-frame low energy constructions, Energy and Buildings 42: 2376 2385 .
11. Nabinger, S., and A. Persily. 2011. Impacts of airtightening retrofits on ventilation rates and energy consumption in a manufactured home, Energy and Buildings 43: 3059 3067.

12. Jesica, F.-A., J. S. Juan, and D. Samuel. 2011. Protocols for measuring the airtightness of multi-dwelling units in Southern Europe, Procedia Engineering 21: $98 \sim 105$.

13. Park, W. S. and J. O. Yoon. 2003. The Field Measurement of Airtightness in the Apartment Buildings. Korea Institute of Ecological Architecture and Environment 9: $43 \sim 50$.

14. Yoon, J. H, J. W. Park, K. S. Lee, N. C. Beak, and U. C. Shin. 2008. A study on the measurement of air-tightness performance of detached houses in Chung-cheong area. Journal of the Korean Solar Energy Society 5: 65 71.

15. Kim, K. L, J. H. Kim, and H. Y. Kim. 2008. Analysis of the air exchange rate which follows in airtightness performance of the studio building. Journal of Architectural Institude of Korea 1: $983 \sim 986$.

16. Koo, S. H, J. H. Jo, M. S. Yeo, and K. W. Kim. 2010. A study on the Characteristics of Airtightness in High-rise Residential Building by Field Measurement. Architectural Institue of Korea 1: $757 \sim 760$.

17. ASTM E 741-00. 2004. Standard Test Method for Determining Air Change in a Single Zone by Means of a Tracer Gas Dilution.

18. ASTM E 779-03. 2004. Standard Test Method for Determining Air Leakage Rate by Fan Pressurization.

19. ISO 9972. 2006. Determination of air permeability of buildings - Fan pressurization method.

20. The Energy Conservatory. 2010. Minneapolis Blower Door Operation Manul for Model3 System. 